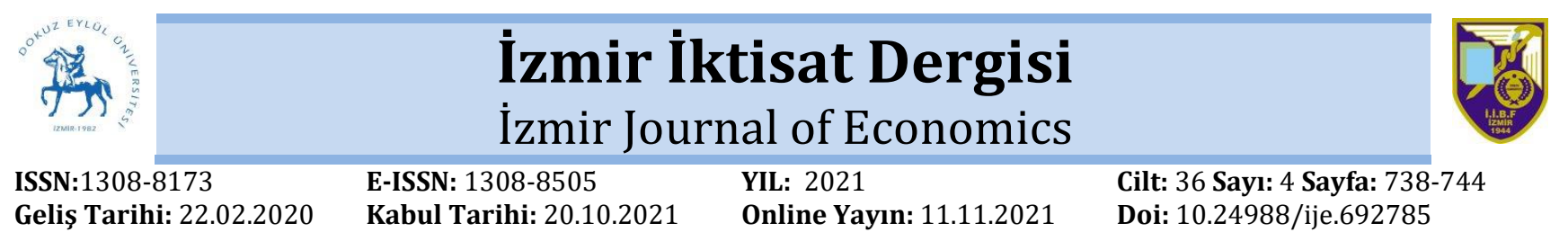

\title{
Immiserizing Growth: A Panel Data Approach for Selected Countries
}

\section{Levent ŞAHIN 1}

\begin{abstract}
In the study, using panel data analysis, the relationship between GDP and global iron, global cotton, global oil, and global copper prices were analyzed under the impoverishing growth hypothesis. The countries analyzed in this study are developing countries such as China, Chile, Czechia, Greece, Hungary, India, South Korea, Malaysia, Pakistan, Peru, Philippines, Poland, Thailand, and Turkey. The data covers the period 2003-2018. The analysis results show that the increase in global cotton and oil prices decreases the GDP of these countries, and the increase in global iron and copper prices increases the GDPs of these countries. Therefore, policymakers should support investment in renewable energy, domestic agriculture, and mining sectors.
\end{abstract}

Keywords: Immiserizing growth hypothesis, GDP, Panel data analysis

Jel Codes: F14, F17, 04

\section{Yoksullaştıran Büyüme: Seçilmiş Ülkeler İçin Bir Panel Veri Yaklaşımı Özet}

Çalışmada, panel veri analizi kullanılarak, yoksullaştıran büyüme hipotezi kapsamında GSYiH ile küresel demir, küresel pamuk, küresel petrol ve küresel bakır fiyatları arasındaki ilişski analiz edilmiştir. Bu çalışmada analizi yapılan ülkeler Çin, Şili, Çekya, Yunanistan, Macaristan, Hindistan, Güney Kore, Malezya, Pakistan, Peru, Filipinler, Polonya, Tayland ve Türkiye gibi gelişmekte olan ülkelerdir. Veriler 2003-2018 dönemini kapsamaktadır. Analiz sonuçları küresel pamuk ve petrol fiyatlarındaki artışın bu ülkelerin GSYIH'lerini düşürdüğünü, küresel demir ve bakır fiyatlarındaki artışın bu ülkelerin GSYIH'lerini artırdığını göstermektedir. Bu nedenle politika yapıcılar yenilenebilir enerji, yerli tarım ve madencilik sektörlerine yatırımı desteklemelidirler.

Keywords: Yoksullaştıran büyüme hipotezi, GSYiH, Panel data analizi

Jel Codes : F14, F17, 04

\section{INTRODUCTION}

Economic growth is a precondition for increasing quality of life and decreasing poverty within society. Economic growth provides improvements in human development, particularly in developing countries.

Economic growth is defined as the rising volume in the production of services and goods compared to an earlier period (Raisová and Durcová, 2014: 184). Numerous factors influence economic growth, such as employment, FDI (foreign direct investment), and capital stock (Upreti, 2015: 38). In addition, specific characteristics of countries affect economic growth (Acemoglu, 2007: 20).

Exports push investments towards more efficient sectors of the economy. Thus production increases (Emery, 1967). If export increases, prices of raw materials increase because export manufacturing raises the demand for raw materials (cotton, petroleum, iron, etc.) globally. Petroleum is used for industrial power. Iron is used as material for railways, tools, machines, and other products. Cotton is used in the textile industry, among others. Prices of raw materials are impacted by the GDP (gross domestic product) of countries.

Immiserizing growth is the decrease or downturn of economic growth despite

ATIF ÖNERÍsí (APA): Şahin, L. (2021). Immiserizing Growth: A Panel Data Approach for Selected Countries. İzmir İktisat Dergisi, 36(4). 738-744. Doi: 10.24988/ije.692785

${ }^{1}$ Assist. Prof. Dr., Cankiri Karatekin University, Faculty of Economics and Administrative Sciences, Department of Economics, Çankırı/Turkey, EMAIL: sahinlvnt@gmail.com ORCID: 0000-0001-7042-7964 


\section{L. ŞAHIN}

increasing economic activity in exports. This issue was first tackled by Edgeworth (1894) and then reviewed again by Bhagwati (1958). There are different descriptions of immiserizing growth in the literature. Bhagwati (1958) explains that the volume of production can increase via economic growth, but the increment cannot occur in terms of trade are destroyed. Johnson's (1967) idea related to immiserizing growth is that if a small open economy faces tariffs, its economy is impacted negatively. According to Samuelson (2004), immiserizing growth can occur in a developing country if its trade partner applies an import policy substituting growth because it changes the terms of trade towards the exporting country.

There are limited relevant studies in the literature. Bhagwati (1958) suggested that economic growth can reduce the level of welfare of a country when the terms of trade worsen. Johnson (1967) explained that if a country has no monopolistic power in world trade, but if the country has a welfare-reducing tariff and import-substitution industrialization policy, economic growth can reduce. Bhattacharyya and Biswas (1987) analyzed the impact of economic growth on welfare. They used the specific-factor model of international trade developed by Batra and Beladi and examined the possibility of Johnson-type immiserizing growth for the developing countries characterized by massive unemployment. According to the result of the analysis, foreign trade increases the level of welfare of a small developing country. According to Kaempfer (1989), immiserizing growth becomes insignificant when globally optimal policy rules are followed, affecting GDP positively. Immiserizing growth is impossible when countries follow the most favorable economic policies. Therefore, countries should leave non-optimal policies. Immiserizing growth is unlikely when the terms of trade are not determined by market power. Choi (2001) noted that if economic growth occurs in the north region of a lowincome, labor-abundant country, the economy in the south decreases. Therefore, the northern, capital-abundant region and poorer southern region separate economically. Choi wrote the paper the related to China as an example.

Kaplinsky (2004) explained that immiserizing growth could appear in a country when welfare falls while economic activities increase. Dinopoulos (2005) suggested that skewed commercial and economic decisions directly negatively impact the relationship between economic growth and welfare. Pryor (2007) indicated that immiserizing growth appears relatively rarely in emerging and developing countries. Collie (2009) stated that if the elasticity of demand for exports becomes sufficiently low within the country, immiserizing growth can be seen. Todorova (2010) investigated the trade of Brazil. Todorova explained that the high elasticity of in-demand sectors, such as manufacturing, cannot increase immiserizing growth. Therefore, countries should join the network of global trade.

The purpose of this paper is to investigate the relationship among prices of raw materials (iron, cotton, petroleum, and copper) and the GDPs of selected countries (China, Chile, Czech Republic, Greece, Hungary, India, South Korea, Malaysia, Pakistan, Peru, the Philippines, Poland, Thailand, and Turkey), in the immiserizing growth hypothesis. Panel data from 2003 to 2018 has been taken from the World Bank. This study has a necessary objective because no studies in the literature contain the same theme, method, countries, and periods.

\section{DATA TYPE AND SOURCES}

This paper consists of 14 selected countries. According to the Morgan Stanly Capital International (MSCI) Emerging Markets Index, the selected countries are developing countries. These countries are China, Chile, Czech Republic, Greece, Hungary, India, South Korea, Malaysia, Pakistan, Peru, the Philippines, Poland, Thailand, and Turkey. The data has been collected from the period of 
2003-2018. All observations are annual. Data on GDP and raw materials prices are obtained from the "World Development Indicators" database of the World Bank. GDP data is in constant 2010 US (The United States of America) Dollars.

\section{METHODOLOGY}

The panel data analysis method is used in this study. In the first step, the cross-section dependency test is applied. In the second step, a second-generation panel unit root test is applied. Finally, the stationarity of variables is tested via unit root tests. Generally, researchers use panel data unit root tests in empirical studies. Thus, there are firstgeneration and second-generation unit root tests. Panel data unit root tests were used initially by Levin and Lin. Nowadays, Levin, Lin \& Chu; Im, Pesaran \& Shin; Breitung; and Fisher-type tests are used. Levin and Lin (1992) developed unit root tests for the model:

$$
\Delta y i, t=p y_{i, t-1}+\alpha_{0}+\delta_{t}+\alpha_{i} \theta_{t}+\varepsilon_{i, t}, t=1, \ldots, T, i=1, \ldots, \mathrm{N}(3.1)
$$

This model contains a time trend and individual effects. The Levin and Lin (1993) test indicates that the null $\mathrm{H}_{0}$ and alternative $\mathrm{H}_{1}$ as follow:

$H_{0}: \mathrm{p}_{1}=\mathrm{p}_{2}=\ldots \ldots=\mathrm{p}_{\mathrm{N}}=\mathrm{p}=0$

$H_{1}: \mathrm{p}_{1}=\mathrm{p}_{2}=\ldots . .=\mathrm{p}_{\mathrm{N}}=\mathrm{p}<0$

Levin, Lin, \& Chu developed a unit root test called the Levin, Lin, \& Chu test (LLC). The test proposes these hypotheses as:

$\mathrm{H}_{0}$ : each time series contains a unit root.

$\mathrm{H}_{1}$ : each time series is stationary.

$\sqrt{\mathrm{N}_{\mathrm{T}}} / \mathrm{T} \rightarrow 0$ is the condition for LLC. $\mathrm{N}$ is a monotonic function and $\mathrm{N}_{\mathrm{T}}$ is the crosssectional dimension (Kunst, 2011: 1). Levin, Lin, \&Chu (2002: 4) presume that each individual has the same first-order partial autocorrelation. However, other variables that are in the error process are allowed to change across individuals freely. Levin, Lin, \& Chu employed three models as follow:

Model 1: $\Delta y i t=\delta y_{i t-1}+\zeta_{i t}$

Model 2: $\Delta y_{i t}=\alpha_{i t}+\delta y_{i t-1}+\zeta_{i t}$

Model3: $\Delta y_{i t}=\alpha_{0 i}+\alpha_{1 i} t+\delta y_{i t-1}+\zeta_{i t}$

where $-2<\delta \leq 0$ for $i=1, \ldots ., N$. Panel unit root test is examined $\mathrm{H}_{0}: \delta=0$ and $\mathrm{H}_{1}: \delta<0$ in the model 1. In addition, yit series have the individual private mean but do not have a time trend in the model 2. Furthermore, yit series have both individual special mean and time trends. $\mathrm{H}_{0}: \delta=0$ and $\alpha_{1 \mathrm{i}}=0, \mathrm{H}_{1}: \delta<0$ and $\alpha_{1 \mathrm{i}} \in \mathrm{R}$. The basic hypothesis of Levin, Lin, \& Chu is as follows (2002: 5):

$$
\begin{gathered}
\begin{array}{c}
\Delta y_{i t}=\delta y_{i t-1} \\
+\sum_{L=1}^{P_{i}} \theta_{i L} \Delta y_{i t-L}+\alpha_{m i} d_{m t} \\
+\varepsilon_{i t}
\end{array} \\
m=1,2,3
\end{gathered}
$$

where $d_{m t}$ is the vector of deterministic variables. $\alpha_{\mathrm{m}}$ is the corresponding vector of coefficients for a particular model $m=1,2,3$. The test recounts the ratio of the long-run to short-run variance.

The Breitung unit root test is different from other unit root tests. Because the data is converted before the regression is calculated for the use of standard t statistics. The Breitung unit root test is used only in balanced panels. The Breitung test can be applied in heterogeneous circumstances too. Breitung applied the model as follows (Breitung, 2000: 5):

$Y_{i t}=\mu_{i}+\beta_{i} t+x_{i t}$

where,

$X_{i t}=\sum_{k=1}^{p+1} \alpha_{i k} X_{i, t-k}+\varepsilon_{i t}$

$\mathrm{X}_{\mathrm{it}}=0$ for $\mathrm{s} \leq 0$. $\varepsilon_{\mathrm{it}}$ is white noise. $\mathrm{E}\left(\varepsilon_{i t}^{2}\right)=\sigma_{i}^{2}$, for all $\mathrm{t}$, $\mathrm{i}$ and some $\delta>0$,

$\mathrm{E}\left|\varepsilon_{i t}\right|^{2+\delta}<\infty$. In addition, $\varepsilon_{\text {it }}$ is independent, $\mathrm{i} \neq$ 


\section{SAHIN}

$\mathrm{j}$, from $\varepsilon_{\mathrm{js}}$ for all $\mathrm{i}$ and $\mathrm{t}$.

Maddala-Wu recommends the Fisher unit root test. There are three reasons for this. First, Fisher tests can show a change related to $\mathrm{T}$ on cross-sections. Second, these tests can be applied for any unit root test coupled with a single time series. And lastly, these tests can be applied for different lag lengths related to the individual ADF regression (Maddala-Wu, 1999: 636).

In addition, there are second-generation unit root tests as follows: Bai and $\mathrm{Ng}$, Moon and Perron, Pesaran, Maddala and $\mathrm{Wu}$, Taylor and Sarno and Chang. Pesaran's (2007) secondgeneration unit root test is applied in the study. The test is known as CADF. CADF regression is as follows (Tatoğlu, 2012: 223):

$\Delta Y_{i t}=\alpha_{i}+p_{i}^{*} Y_{i t-1}+d_{0 Y_{t-1}}^{-}+d_{1} \Delta_{Y_{t}}+{ }^{-} \varepsilon_{i t}$

In the third step, the Hausman test is applied. Finally, the Hausman test is utilized to choose between the fixed and the random estimators.

In the fourth step, a panel data analysis is applied. Panel data is gathered together in horizontal cross-sectional observations belonging to units (companies, individuals, countries, and households) at a certain period (Greene, 2012: 383-384). Panel data is based on time-series observations. Two dimensions are section dimensions and time series. Panel data has a complicated and hierarchical structure (Hsiao, 2006: 1). It is possible to clarify the reasons as (Hsiao, 2006: 3-6):

1. The Panel data method gives the chance to test more accurate model parameters.

2. The panel data method can verify influences that are not confirmed readily by carrying out pure cross-section data and pure time-series observations.

3. The panel data method makes particular the opportunity to examine for individualspecific variables heterogeneity.

4. The method of panel data is proper for controlling the dynamics of adjustment.
5. The panel data method is suited to tackle complicated behavioral models.

6. The problems related to the regression results can be solved if the panel data model is structured accurately.

The panel data model is written as follows (Baltagi, 2005: 11):

$y_{i t}=\alpha+X{ }^{\prime}$ it $\beta+u_{i t}, \quad i=1, \ldots \ldots . ., N ; \quad t=1, \ldots T(3.9)$

where, $\mathrm{y}$ is denoting the dependent variable, $\alpha$ is a scalar, $\mathrm{X}$ is $\mathrm{i}, \mathrm{t}$, the observation on $\mathrm{K}$ explanatory variables. i denotes the crosssection dimension (countries, individuals, households, firms), $\mathrm{t}$ denotes time and $\beta=\mathrm{Kx} 1$.

Hypothesis: The GDP of an emerging country decreases when global prices of iron, cotton, petroleum, and copper increase.

\section{EMPIRICAL RESULTS}

In this study, a panel data method is used, covering the period of 2003-2018. The study concerns the prices of raw materials [copper(fcor), cotton(fcot), iron(fir), and petroleum(foi)]. Also, fgdp= GDP and $\mathrm{f}=$ the first difference.

Table 1: Cross-section dependency test

\begin{tabular}{|l|l|l|}
\hline Tests & Statistic & $p$-value \\
\hline LM & 200.5 & 0.0000 \\
\hline LM adj & 6.75 & 0.0000 \\
\hline LM CD & 2.642 & 0.0082 \\
\hline
\end{tabular}

Source: Author's calculations

According to the cross-section dependency test results, there is a dependency because $\mathrm{p}$ values are lower than the critical value $(0,05)$ (Table 1). Therefore, second-generation unit root tests should use to determine the stability.

Table 2: Second generation unit root test

\begin{tabular}{|l|l|l|l|l|l|}
\hline Variables & t-bar & cv10 & cv5 & cv1 & p-values \\
\hline fgdp & -1.215 & -2.160 & -2.280 & -2.520 & 0.961 \\
\hline fcot & 2.610 & -2.160 & -2.280 & -2.520 & 1.000 \\
\hline fir & 2.610 & -2.160 & -2.280 & -2.520 & 1.000 \\
\hline foi & 2.610 & -2.160 & -2.280 & -2.520 & 1.000 \\
\hline fcor & 2.610 & -2.160 & -2.280 & -2.520 & 1.000 \\
\hline
\end{tabular}

Source: Author's calculations

The Second Generation Unit Root Test (Pesaran-CADF) panel unit root test is applied to determine the stability of the variables, and 
fgdp, fcot, fir, foi, and fcor are stable in the CADF test (Table 2).

Table 3: Hausman test

\begin{tabular}{|l|l|}
\hline Variable & gdp \\
\hline Prob>chi2 & 1.000 \\
\hline Result & Random \\
\hline
\end{tabular}

Source: Author's calculations

The Hausman test is used to determine fixed or random tests. The result of fgdp is higher than 0,05 . Therefore, random is preferred (Table 3 ).

Table 4: Heteroscedasticity, autocorrelation, inter-unit correlation tests

\begin{tabular}{|l|l|l|l|}
\hline Tests & & fgdp & Result \\
\hline \multirow{4}{*}{ Heteroscedasticity } & w 0 & 0.0060 & \multirow{2}{*}{+} \\
\cline { 2 - 3 } & w 50 & 0.0051 & \multirow{2}{*}{ w 10 } \\
\cline { 2 - 3 } Autocorrelation & Bhargava- DW & 1.24 & \multirow{2}{*}{+} \\
\cline { 2 - 3 } & Baltagi Wu-LBI & 1.34 & \\
\hline $\begin{array}{l}\text { Inter-Unit } \\
\text { Correlation }\end{array}$ & & 0.04 & \multirow{2}{*}{+} \\
\hline
\end{tabular}

Source: Author's calculations

The fgdp equation has heteroscedasticity, autocorrelation, and inter-unit correlation problems, because w0, w50, and w10 values are lower than 0,05 . Therefore, there is a heteroscedasticity problem. In addition, autocorrelation values are lower than 2 (critical value). Therefore, there is an autocorrelation problem. Also, inter-unit correlation value is lower than 0,05 (critical value) (Table 4). Therefore, there is an interunit correlation problem.

Table 5: Panel data analysis result for GDP

\begin{tabular}{|c|c|c|c|c|c|}
\hline fgdp & Coef. & Std. Err. & $\mathrm{z}$ & $\mathrm{P}>|\mathrm{z}|$ & $\begin{array}{l}{[95 \% \text { Conf }} \\
\text { Interval] }\end{array}$ \\
\hline fcot & $-.006 * *$ & .0022 & -2.83 & 0.005 & $\begin{array}{l}-.010 \\
-.001\end{array}$ \\
\hline fir & $.024 * *$ & .0016 & 14.68 & 0.000 & $\begin{array}{l}.021 \\
.027\end{array}$ \\
\hline foi & $-.019 * *$ & .0026 & -7.32 & 0.000 & $\begin{array}{l}-.024 \\
-.014\end{array}$ \\
\hline fcop & $.042 * *$ & .0023 & 17.59 & 0.000 & $\begin{array}{l}.037 \\
.046\end{array}$ \\
\hline cons & .037 & .0006 & 62.03 & 0.000 & $\begin{array}{l}.036 \\
.039 \\
\end{array}$ \\
\hline
\end{tabular}

**: Statistically significant at 5\%.

Source: Author's calculations

Driscoll-Kraay panel data test is used to overcome heteroscedasticity, autocorrelation, and inter-unit correlation problems. According to the panel data test results, the fcot independent variable impacts the fgdp dependent variable negatively because if fcot increases $1 \%$, the fgdp decreases by $-0,006 \%$. The foi independent variable negatively impacts the fgdp dependent variable because if foi increases $1 \%$, the fgdp decreases by $0,019 \%$. The fir independent variable positively impacts the fgdp dependent variable because if fir increases 1\%, the fgdp increases by $0,024 \%$. The fcop independent variable impacts the fgdp dependent variable positively because if fir increases 1\%; the fgdp increases by $0,037 \%$ (Table 5 ).

\section{CONCLUSION}

This study is dependent on the data available from 2003-2018 for 14 emerging countries to illustrate the impact that the values of global iron, cotton, petroleum, and copper prices have on GDP for the period 2003-2018. The Driscoll-Kraay panel data test is applied. The analysis shows that the GDP of the 14 emerging countries increases if global iron and copper prices increase, but it decreases the GDP of the 14 emerging countries if global cotton and petroleum prices increase. These results are consistent with the Immiserizing hypothesis of Jagdish Bhagwati.

According to this analysis, the increase in global cotton and petroleum prices increases the production costs of the 14 developing countries that import these raw materials. Consequently, this situation lowers the GDP of these countries.

Therefore, policymakers of these developing countries should take the following measures to reduce production costs in their countries:

1. Policymakers should focus on the use of renewable energy sources from within their countries. Therefore decreasing energy costs in the ensuing years.

2. Policymakers should focus on developing iron, copper, and other mines in their countries. This would reduce the import volume of these raw materials. In other words, 
governments should focus on using domestic raw materials.

3. Policymakers should search for suitable production conditions (irrigation, soil analysis, etc.) in their countries to produce cotton and other industrial, agricultural products.
4. More monetary resources should be allocated for research and development.

\section{REFERENCES}

Acemoğlu, D. (2007). Introduction to modern economic growth: Parts 1-5. Access address: http://users.econ.umn.edu/ guvenen/Daron Book1.pdf

Baltagi, H. B. (2005). Econometric analysis of panel data. West Sussex: John Wiley \& Sons.

Bhagwati, J. (1958). Immiserizing growth: A geometrical note. Review of Economic Studies, 25(3), 201-205.

Bhattacharyya, A., Biswas, B. (1987). Specific factors, unemployment and immiserizing growth in a small open economy. Utah: Economic Research Institute Study Papers. Paper 450.

Breitung, J. (2000). The local power of some unit root tests for panel data. Access address: https://www.econstor.eu/bitstream/10419/ 61764/1/722394276.pdf

Choi, E. K. (2001). Neighbour-immiserizing growth: The Asian Crisis. The Japanese Economic Review, 4(52), 405-416.

Collie, D. R. (2009). Immiserizing growth and the metzler paradox in the ricardian model. Cardiff: Cardiff Business School Working Paper Series, ISSN 1749-6101, E2009/11.

Dinopoulos, E. (2005). Immiserizing growth in expanding economies. Access address: http://www.columbia.edu/ ap2231/jbconfe rence/Papers/Dinopoulos_Bhagwati\%20Conf erence.pdf

Edgeworth, F.Y. (1894). Theory of international values. The Economic Journal, 4(16), 606-638.

Emery, R.F. (1967). The relation of exports and economic growth. International Review for Social Sciences, 20(4), 470-486.
Greene, H. W. (2012). Econometric analysis. Westford: Pearson Education.

Hsiao, C. (2006). Panel data analysis advantages and challenges. California: IEPR Working Paper No: 06. 49.

Johnson, H.G. (1967). The possibility of income losses from increased efficiency or factor accumulation in the presence of tariffs. The Economic Journal, 77(305), 151-154.

Kaempfer, G. W. (1989). Immiserising growth with globally optimal policie. Journal of Economic Studies, 16(1).

Kaplinsky, R. (2004). Immiserising growth. Accessaddress:http://www.soc.duke.edu/sloa n_2004/Papers/Memos/Kaplinsky_immiseris ing\%20growth_25June04.pdf

Levin, A., Lin, C. F. (1992), "unit root test in panel data: Asymptotic and finite sample properties. San Diego: University of California at San Diego, Discussion Paper No: 92-93.

Levin, A., Lin, C. F. (1993). Unit root test in panel data: New results. San Diego: University of California at San Diego, Discussion Paper No: 93-56.

Levin, A., Lin, C. F., Chu, J. (2002). Unit root tests in panel data: Asymptotic and finite sample properties. Journal of Econometrics, 108(1), 124.

Maddala, G.S., Shaowen, W. (1999). A comparative study of unit root tests with panel data and new simple test. Oxford Bulletinin of Economics and Statistics, Special issue, 631652.

Pryor, F.L. (2007). Immiserizing growth as seen by Bhagwati, Samuelson and others. 
Journal of Economic Education, 38(2), 208214.

Raisová, M., Ďurčová, J. (2014). Economic growth-supply and demand perspective. Procedia Economics and Finance, 15, 184-191.

Samuelson, P. A. (2004). Where Ricardo and Mill rebut and confirm arguments of mainstream economists supporting globalization. Journal of Economic Perspectives, 18(3), 135-47.

Upreti, P. (2015). Factors affecting economic growth in developing countries. Access address: http://business.uni.edu/economics/ themes/Upreti. pdf

Tatoğlu, F. Y. (2012). İleri panel veri analizi. İstanbul: Beta yayınları.

Todorova, T. (2010). World demand as a determinant of immiserizing growth. iBusiness, 2(3): 255-267. 